\title{
PRAKTIK AL-HIJR DALAM PENYELESAIAN NUSYÛZ DI PENGADILAN AGAMA
}

\author{
Ahmad Izzuddin \\ Fakultas Syariah UIN Maulana Malik Ibrahim Malang \\ ashfazudin@yahoo.co.id
}

\begin{abstract}
Abstrak
Nusyîz cases of wife can be solved in three ways: giving good advice, al-hijr or separating beds, and beatings. This study aimed to analyze the background and the implementation of al-hijr performed by the parties litigating in the Religious Court. Through the qualitative descriptive approach, it is known that the parties who filed the divorce did al-hijr, by reason of infidelity, quarrels, prolonged disputes, and expulsion by one party. The implementation of al-hijr is not appropriate with Islamic law because most of al-hijr implementation exceed the maximum time limit. In addition, most couples do al-hijr by leaving the house, cutting off the communication, and not providing any living both physically and spiritually.

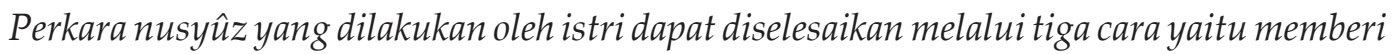
nasihat yang baik, al-hijr atau pisah ranjang, dan pemukulan. Penelitian ini bertujuan menganalisis latar belakang dan pelaksanaan al-hijr yang dilakukan oleh para pihak berperkara di Pengadilan Agama. Melalui pendekatan diskriptif kualitatif diketahui bahwa para pihak yang mengajukan perceraian melakukan al-hijr karena alasan perselingkuhan, pertengkaran, perselisihan yang berkepanjangan, pengusiran oleh satu pihak. Pelaksanaan al-hijr ini belum sesuai dengan hukum Islam karena sebagian besar al-hijr dilakukan melebihi batas waktu maksimal. Selain itu, sebagian besar pasangan melakukan al-hijr dengan cara meninggalkan rumah, memutus komunikasi, tidak memberikan nafkah dan lahir batin.
\end{abstract}

Kata Kunci : al-Hijr, Nusyûz, Perceraian

Perceraian menjadi salah satu persoalan sosial yang menimbulkan kekhawatiran banyak pihak. Fenomena ini terjadi hampir di seluruh wilayah Indonesia, dengan intensitas rendah hingga mengkhawatirkan. Berdasarkan data Direktorat Jenderal Peradilan Agama Mahkamah Agung, terjadi 354.371 kasus perceraian pada tahun 2015 dengan rincian 87.194 kasus terjadi di provinsi Jawa Timur. Salah satu wilayah dengan tingkat perceraian mengkhawatirkan adalah Malang, Jawa Timur. ${ }^{1}$

${ }^{1}$ Direktorat Jenderal Badan Peradilan Agama, Data Jenis Perkara Nasional Tahun 2015 (online) (dapat
Data penerimaan perkara Pengadilan Agama menunjukkan kenaikan angka perceraian yang signifikan. Dalam rentang waktu tiga tahun, dari 2010 hingga 2013, terjadi kenaikan angka perceraian sebesar $10 \%$. Faktor utama penyebab perceraian syiqâq atau perselisihan terus menerus di antara pasangan suami istri. Perselisihan tersebut dilatarbalakangi oleh berbagai masalah seperti tidak harmonisnya hubungan suami-istri, krisis akhlak, tidak adanya tanggung jawab, cemburu, ekonomi,

diakses di http://infoperkara.badilag.net, tanggal 21 Maret 2015) 
gangguan pihak ketiga, dan kawin paksa. ${ }^{2}$

Syiqâq dalam khazanah hukum Islam, merupakan kondisi yang terjadi akibat terjadinya nusyûz, baik yang dilakukan oleh suami atau istri dan tidak dapat diselesaikan dengan baik. Sedangkan nusŷuz sendiri merupakan keengganan salah satu pihak dari suami istri maupun keduanya untuk memenuhi kewajiban dan tanggung jawab dalam rumah tangga. ${ }^{3}$ Pada dasarnya, al-Qur'an telah memberikan tahapan-tahapan penyelesaian nusyûz agar tidak berlanjut kepada syiqâq sebagaimana firman Allah SWT. dalam Q.S. al-Nisa [4]: 34 dan Q.S. al-Nisa [4]: 128. Meskipun demikian, praktek di masyarakat tidak jarang menimbulkan persepsi dan cara yang berbeda dalam menerapkan ajaran Islam. Pasangan suami-istri yang mengajukan permohonan cerai atau gugat cerai, telah melakukan pisah ranjang terlebih dahulu. Praktik pisah ranjang yang telah menjadi tradisi di masyarakat menimbulkan pertanyaan adakah korelasi dengan kosep alhijr dalam penyelesaian konflik rumah tangga atau justru sebaliknya.

Nusyûz dan Solusinya dalam Al-Qur'an

Konflik rumah tangga selain syiqâq yang diterangkan al-Qur' an adalah nusyûz. Dalam Q.S. al-Nisa [4]: 34 Allah SWT. berfirman:

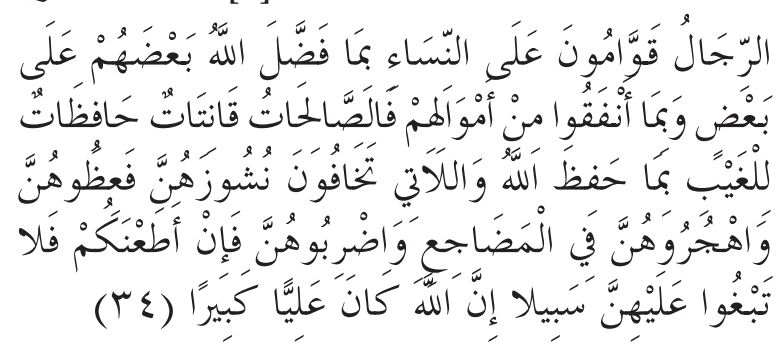

Artinya: Kaum laki-laki itu adalah pemimpin bagi kaum wanita, oleh karena Allah telah melebihkan sebahagian mereka (laki-laki) atas sebahagian yang lain (wanita), dan karena mereka (laki-laki) telah menafkahkan sebagian dari harta mereka. Sebab itu

${ }^{2}$ Direktorat Jenderal Badan Peradilan Agama, Data Faktor Penyebab Perceraian Nasional Tahun 2015 (online) (dapat diakses di http://infoperkara.badilag.net, tanggal 21 Maret 2015)

${ }^{3}$ Ahmad Musthofa al-Marâghi, Tafsîr al-Marâghi, Juz V (Mesir: Maktabah Musthofa al-Baby al-Halaby, 1986), h. 84 maka wanita yang saleh, ialah yang taat kepada Allah lagi memelihara diriketika suaminya tidak ada, oleh karena Allah telah memelihara (mereka). Wanitawanita yang kamu khawatirkan nusyûznya, maka nasehatilah mereka dan pisahkanlah mereka di tempat tidur mereka, dan pukullah mereka. Kemudian jika mereka mentaatimu, makajanganlah kamu mencaricari jalan untuk menyusahkannya. Sesungguhnya Allah Maha Tinggi lagi Maha Besar

Ayat di atas menjelaskan konsep nusyûz yang dilakukan oleh istri terhadap suaminya. Sementara nusŷuz yang dilakukan oleh suami atas istrinya dijelaskan dalam Q.S. al-Nisa [4]: 128:

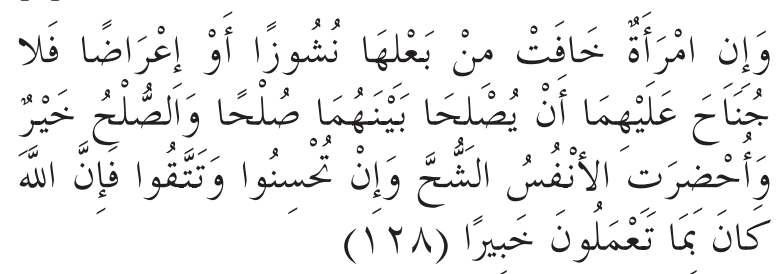

Artinya: Dan jika seorang wanita khawatir akan nusyûz atau sikap tidak acuh dari suaminya, maka tidakmengapabagikeduanya mengadakan perdamaian yang sebenar-benarnya, dan perdamaian itu lebih baik (bagi mereka) walaupun manusia itu menurut tabiatnya kikir. Dan jika kamu bergaul dengan istrimu secara baik dan memelihara dirimu (dari nusyûz dan sikap tak acuh), maka sesungguhnya Allah adalah Maha Mengetahui apa yang kamu kerjakan.

Nusyûz secara etimologi berasal dari kata النَشَزْ di suatu dataran. ${ }^{4}$ Seorang istri dikatakan nusyûz apabila ia merasa lebih tinggi derajatnya dibanding suami, meninggalkan perintah suami, berpaling dari suami dan/atau membenci keberadaan suaminya. ${ }^{5}$ Atau dengan kata lain, nusyûz terjadi karena istri meninggalkan kewajibannya dan melalaikan hak suami dalam rumah tangga. Beberapa hal yang mengindikasi akan terjadi nusŷuz seperti keluar rumah tanpa izin dari suami, sikap berpaling dari suami, berwajah masam, merasa berat apabila

\footnotetext{
${ }^{4} \mathrm{Abu}$ Ishâq al-Zujâj, Ma'ani al-Qur'an wa I'râbuh, Juz II (Beirut: 'Âlam al-Kutub, 1988), h.47

${ }^{5}$ Muhammad 'Ali al-Shâbûny, Mukhtashar Ibn Katsîr, Juz I (Beirut: Dâr al-Qur'an al-Karîm, 1981), h. 386
} 
dipanggil dan hal tersebut berbeda dari harihari sebelumnya dimana istri biasa bersikap lembut dan ceria, atau ucapannya yang ketus berbeda dari sebelumnya yang lemah lembut. ${ }^{6}$ Meskipun demikian, tidak semua hal di atas dikategorikan indikator nusyûz. Misalnya istri sudah terbiasa berkata kasar kepada suami, meskipun istri berdosa apabila menyakiti suami dengan perkataannya hal tersebut

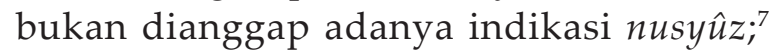
Keengganan istri untuk melakukan pekerjaan rumah tangga seperti memasak, mencuci dan lain sebagainya. Karena hal tersebut bukanlah termasuk dari kewajiban seorang istri. Atau istri keluar dari rumah tanpa izin suami apabila rumah tersebut bukanlah rumah suami dan untuk kepentingan yang mendesak. ${ }^{8}$ Menolak ajakan suami karena sakit. ${ }^{9}$ Sedangkan nusŷuznya suami adalah keengganan suami untuk melaksanakan kewajibannya seperti memberi nafkah lahir dan batin, berbuat adil dalam menggilir dan bermalam di rumah istri-istrinya secara merata.

\section{Penyelesaian Nusyûz Perpektif al-Qur'an dan Hadist}

Nusyûz yang dilakukan istri sebagaimana tercantum dalam Q.S. al-Nisa[4]: 34 dapat diselesaikan dengan tiga cara yaitu memberi mauidzah atau nasihat, melakukan al-hijr dan memukul. Para fuqaha berbeda pendapat mengenai urutan dari ketiga metode tersebut. Perbedaan ini berkaitan dengan adanya keharusan melawati dari cara pertama ke cara berikutnya jika tidak berhasil atau boleh dilakukan berdasarkan kebutuhan. Penggunaan huruf 'ataf wawu pada ayat tersebut meskipun pada dasarnya tidak mengharuskan tartib akan tetapi dalam konteks ini banyak ulama yang

\footnotetext{
${ }^{6}$ Wahbah al-Zuhaily, al-Figh al-Islâmy wa Adillatuh,Juz IX (Damaskus: Dâr al-Fikr, 2006), h.322

${ }^{7}$ Nawawi, Raudhat al-Thâlibîn wa 'Umdat al-Muftîn, Juz VII (Beirut: al-Maktab al-Islâmy, 1991), h. 369

${ }^{8}$ Nawawi, Raudhat.. Juz IX, h. 60

${ }^{9}$ Nawawi, Minhâj al-Thâlibîn wa 'Umdat al-Muftîn fi al-Fiqh (Beirut: Dâr al-Fikr, 2005), h.264
}

berpendapat keharusan adanya tartib. ${ }^{10}$

Meskipun demikian, terdapat mufassir yang berpendapat bahwa keharusan seorang suami menyelesaikan problem nusŷuz istri melalui tiga metode tersebut secara runut, jika suami masih menduga bahwa istri akan melakukan nusyûz. Akan tetapi, jika perbuatan nusyûz tersebut telah nyata terjadi, misalnya suami melihat istrinya memasukkan pria lain tanpa izin darinya atau keluar rumah tanpa izin darinya, maka suami tidak wajib mentaati urutan tersebut. Dengan kata lain, suami dapat memilih salah satu cara yang diperlukan untuk mengembalikan ketaataan istri kepadanya. ${ }^{11}$

\section{al-Hijr sebagai Solusi Persoalan Nusyûz}

Salah satu cara yang dapat ditempuh oleh suami atas perilaku nusyûz istri adalah al-hijr. Metode ini menurut mayoritas ulama dilakukan setelah memberinya mauidzah atau nasihat-nasihat kepada istri. Para Fuqaha berbeda dalam memaknai al-hijr. Sebagian fuqaha berpendapat bahwa al-hijr adalah tidak melakukan hubungan biologis dengan istri pada masa nusyûz. Implementasi al-hijr dalam rumah tangga juga bisa ditandai dengan berkata dengan keras kepada istri tidak sekedar memberi mauidzah. Sedangkan ulama lain berpendapat bahwa al-hijr dilakukan dengan cara membatasi gerak istri di dalam rumah sebagai bentuk ikatan kepada dirinya agar kembali sadar. ${ }^{12}$ Rasulullah Saw. memberikan penjelasan tentang tata cara seorang suami menunut haknya dalam berumah tangga:

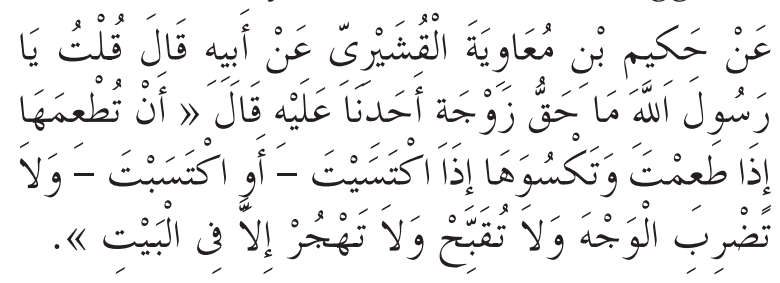

\footnotetext{
${ }^{10} \mathrm{Al}$-Zuhaily, al-Figh al-Islâmy .. Juz IX, h. 95

${ }^{11}$ Fakr al-Dîn al-Râzy, Mafâtîh al-Ghaib, Juz X (Beirut: Dâr Ikhyâ al-Turâts, 1420 H), h.72

${ }^{12}$ Syarbîny, Mughni al-Muhtâj, Juz IV (Beirut: Dâr alKutub al-'Ilmiyyah, 1994), h.426
} 
Artinya: Dari Hakim bin Mu'awiyah al-Qusyairi dari ayahnya: Aku bertanya wahai Rasulullah: "apa hak seorang istri atas suami?" Rasul menjawab "memberi makan istri apa yang kamu makan, memberi pakaian sebagaimana yang kamu pakai atau kamu cari, jangan kamu pukul wajah, jangan engkau jelek-jelekkan, jangan melakukan al-hijr kecuali di rumah. (HR. Abu Dawud) ${ }^{13}$

\section{Batasan dan Tujuan Praktik al-Hijr dalam Islam}

Berdasarkan hadist riwayat Abu Dawud di atas, konsep al-hijr dapat dilakukan secara sewenang-wenang, akan tetapi ada batasanbatasan yang harus dita' ati oleh seorang suami yaitu: a) Tidak boleh mengusir istri dari rumah; b) Tidak boleh mengumbar masalah al-hijr keluar dari rumah karena masalah ini adalah masalah domestik rumah tangga; c) Tidak melebihi batas maksimal dalam al-hijr sebagaimana dirumuskan oleh para fuqaha. Imam Syafi'i membatasi al-hijr dalam bentuk tidak mengajak bicara hanya maksimal 3 hari sebagaimana tercantum dalam hadits riwayat Muslim:

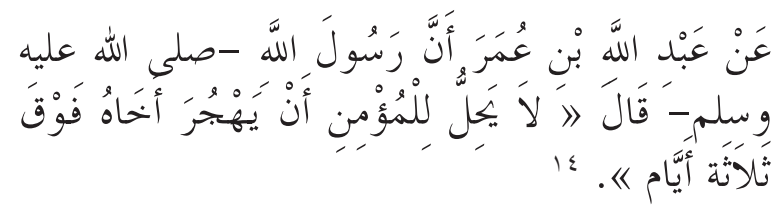

Artinya: dari sahabat Abdullah ibn "Umar, Sesungguhnya Rasulullah Saw bersabda tidak diperbolehkan seorang muslim menjauhi (mendiamkan) saudaranya lebih dari tiga hari." (HR. Muslim)

Dalam hadits yang lain Rasulullah Saw. bersabda:

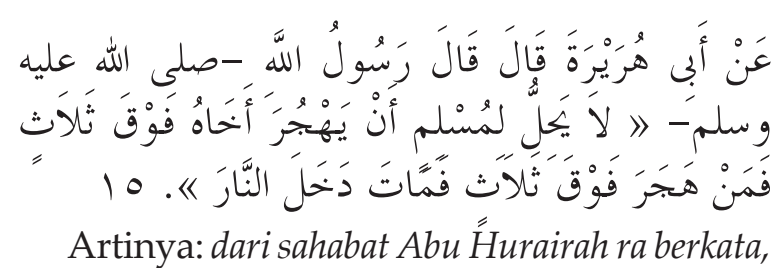

\footnotetext{
${ }^{13} \mathrm{Abu}$ Daud, Sunan Abi Daud, Juz II (Beirut: Maktabah al-'Ashriyyah, tt), h.244

${ }^{14}$ Muslim, Shahîh Muslim, Juz IV (Beirut: Dâr Ikhyâ al-Turâts al-'Araby, tt), h.1984
}

${ }^{15}$ Abu Dâud, Sunan Abi..., h.279
Rasulullah Saw. bersabda "Dan tidak diperbolehkan seorang muslim menjauhi (mendiamkan) saudaranya lebih dari tiga malam, barang siapa mendiamkan saudaranya di atas tiga hari ketika ia meninggal maka masuk neraka." (HR. Abu Dawud)

Sedangkan batas maksimal untuk al-hijr dalam pengertian tidak melakukan hubungan seksual dengan istri adalah empat bulan sebagaimana masa maksimal sumpah $i a^{\prime}{ }^{16}$ Pemberlakuan al-hijr diharapkan mampu memberikan pemahaman kepada istri terkait posisinya dan kebutuhannya terhadap keluarga. Meskipun bagi istri yang sudah terbiasa hidup terpisah dengan suami cara ini dirasa tidak efektif. ${ }^{17}$ Salah satu penyebabnya adalah ketidakmampuan suami mengindentifikasi sebab dari terjadinya perselisihan. Selain itu, Pengetahuan terhadap karakter istri dan sikap kedewasaan sikap suami dapat dijadikan modal dalam penanganan perkara syiqaq akibat nusyûz. Sikap kedewasaan suami terimplementasi dalam perilaku memaafkan, tidak memarahi dan mengampuni sebagaimana firman Allah SWT. dalam Q.S. al-Taghâbun [64]: 14:

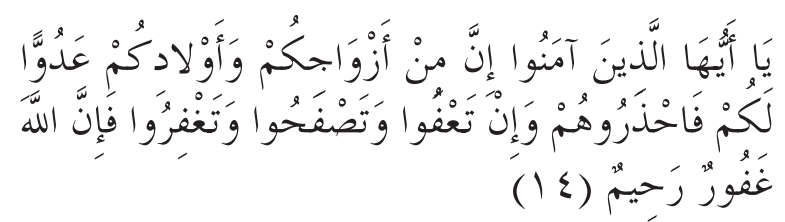

Artinya: Hai orang-orang mukmin, sesungguhnya di antara istri-istrimu dan anak-anakmu ada yang menjadi musuh bagimu maka berhati-hatilah kamu terhadap mereka dan jika kamu memaafkan dan tidak memarahi serta mengampuni (mereka) maka sesungguhnya Allah Maha Pengampun lagi Maha Penyayang.

Dalam khazanah hukum Islam, al-hijr bertujuan memberikan ruang introspeksi dan perbaikan pola komunikasi suami istri secara bertahap. Jeda waktu yang terjadi dalam praktikal-hijr diharapkan mampu mengurangi ego salah satu pasangan yang melakukan

\footnotetext{
${ }^{16}$ Mahmûd al-Mishry Abu 'Amâr, al-Zawâj al-Islâmy al-Sa'îd (Kairo: Dar al-Shafa, 2006), h.773

${ }^{17}$ Kamil al-Hayali, Solusi Islam...., h.51
} 
nusŷิz, serta menumbuhkan kembali rasa membutuhkan kehadiran pasangan. Hal ini relevan dengan pendapat Iris Krasnow yang menyatakan bahwa faktor yang menjadikan suatu hubungan menjadi lebih kuat adalah ketidakhadiran salah seorang pasangan untuk waktu tertentu. Meskipun, sebagian besar pasangan suami istri cenderung berpikir bahwa tidak adanya komunikasi dalam waktu tertentu akan menimbulkan konflik. Iris tidak merekomendasikan pasangan suami-istri agar jarang berkomunikasi. Akan tetapi, adanyajeda komunikasi diharapkan mampu menimbulkan kerinduan dan keinginan untuk menjalin hubungan kembali. Begitu pula dengan pisah ranjang yang dilakukan oleh suami terhadap istri yang melakukan nusyûz. Pisah ranjang hanya dalam pengertian perbedaan ruangan tidur dalam satu rumah. Cara seperti ini digunakan oleh pasangan yang masih saling mencintai dan memiliki keinginan kuat mempertahankan rumah tangganya. Dan tidak sedikit pasangan yang berhasil memperbaiki kualitas hubungan rumah tangganya melalui cara ini. ${ }^{18}$

\section{Problematika Penerapan Al-Hijr dalam Masyarakat}

Salah satu faktor yang menyebabkan perceraian adalah kurang pemahaman masyarakat terhadap hakekat dan makna perkawinan. Kondisi ini disebabkan kurangnya sosalisasi dan pembinaan terhadap pasangan suamiistri baik pra maupun pasca perkawinan. Lemahnya pemahaman tersebut berimplikasi terhadap pola relasi suami-isti ketika terjadi konflik. Sebagian masyarakat memahami al-hijr dengan pisah ranjang ataupun pisah rumah, baik salah satu atau keduanya meninggalkan kediaman bersama. Atau dalam kasus lain salah satu pihak mengusir pasangannya dari kediaman bersama. Kondisi ini dianggap pilihan yang lazim dilakukan bagi suami-istri yang terlibat konflik. Akibatnya, al-hijr tidak lagi dapat berfungsi sebagai masa perenungan

${ }^{18} \mathrm{http}: / / \mathrm{ww} w . v e m a l e . c o m /$ relationship/ intim/16399-pisah-ranjang-memperkuat-ikatansuami-istri.html dan kontemplasi untuk menyelesaikan masalah rumah tangga.

Konsep al-hijr pada dasarnya merupakan salah tugas dari suami sebagai qawwôm terhadap istri. Kata qawwâm sebagaimana termaktub dalam Q.S. al-Nisa [4]: 34 lazim diartikan sebagai pemimpin. Meskipun kata pemimpin dalam al-Qur'an biasa disebut juga dengan kata imâm atau malik. Kata qawwâm terambil dari kata قام yang bermakna berdiri ataupun lurus. Sehingga kata qawwâm berarti pemimpin yang mengurus kepentingan istri dan menjaganya dari hal-hal yang membahayakan. Hal tersebut disebabkan dua aspek kelebihan laki-laki baik yang bersifat fitrah dengan kekuatan fisiknya dan yang bersifat kasbiyah dengan kemampuan mencari nafkah untuk keluarga. ${ }^{19}$ Kesuksesan al-hijr dalam penanganan nusyuz memiliki hubungan erat dengan terlaksananya fungsi qawwâm suami seperti: a) kemampuan memberikan nafkah yang ideal bagi istri; $b$ ) kemampuan menjadi imam yang baik dalam keluarga; c) kemampuan memberikan tempat tinggal yang layak kepada istri; d) kemampuan terhadap pemahaman dan pengajaran agama yang baik kepada istri dan anak-anak; e) kemampuan manajerial penyelesaian konflik rumah tangga.

\section{Metode Penelitian}

Penelitian ini termasuk penelitian lapangan karena dilakukan di Pengadilan Agama Kabupaten Malang. ${ }^{20}$ Melalui pendekatan diskriptif kualitatif, ${ }^{21}$ peneliti melakukan identifikasi terhadap latar belakang dan praktik al-hijr yang dilakukan oleh pasangan suamiistri yang berperkara di Pengadilan Agama Malang. Sumber data penelitian ini adalah data primer, ${ }^{22}$ yaitu pasangan suami-istri yang

${ }^{19}$ Al-Marâghi, Tafsîr al-Marâghy, Jilid V (Kairo: Musthafa al-Bâby al-Halaby, 2005), h.84

${ }^{20}$ Lexy J Moelong, Metodologi Penelitian Kuantitatif ( Bandung: PT Rosda karya, 2002), h.135.

${ }^{21}$ Sugiyono, Metode Penelitian Pendekatan Kuantitatif, Kualitatif dan RED (Bandung: Alfabeta, 2007), h.50

${ }^{22}$ Amiruddin, Zainal Asikin, Pengantar Metode Penelitian Hukum ( Jakarta: PT Grafindo Persada, 2004), h. 30 . 
sedang berperkara di Pengadilan Agama yang diwawancarai ketika mereka melakukan mediasi di hadapan mediator dan data sekunder yaitu jurnal ataupun laporan-laporan penelitian yang terkait dengan penelitian. Sumber data tersebut diperoleh melalui wawancara dengan menggunakan panduan wawancara (interview guide). ${ }^{23}$

\section{Hasil dan Pembahasan}

\section{Usia Perkawinan, Alasan Perceraian dan Masa al-Hijr}

Informan penelitian ini adalah pasangan suami-istri yang mengajukan perceraian di Pengadilan Agama Kabupaten Malang. Adapun informasi terkait dengan usia perkawinan para informan dalam penelitian ini sebagai berikut:

\begin{tabular}{lll}
\hline \multicolumn{1}{c}{ No. } & \multicolumn{1}{c}{ Lama Perkawinan } & \multicolumn{1}{c}{ Jumlah } \\
\hline 1. & 0 s.d 1 tahun & 1 pasangan \\
\hline 2. & 1 s.d 2 tahun & 0 pasangan \\
\hline 3. & 2 s.d 4 tahun & 0 pasangan \\
\hline 4. & 4 s.d 6 tahun & 1 pasangan \\
\hline 5. & 6 s.d 8 tahun & 0 pasangan \\
\hline 6. & 8 s.d 10 tahun & 2 pasangan \\
\hline 7. & 10 s.d 15 tahun & 2 pasangan \\
\hline 8. & 15 s.d 21 tahun & 4 pasangan \\
\hline
\end{tabular}

Pasangan suami-istri di atas mengajukan perceraian dengan alasan syiqaq ataupun nusyûz, baik dari pihak suami maupun pihak istri. Hal ini relevan dengan data alasan perceraian Pengadilan Agama Kabupaten Malang. Pada tahun 2015, perceraian di dominasi oleh alasan tidak adanya keharmonisan, masalah ekonomi, tidak ada tanggung jawab, dan gangguan pihak ketiga. ${ }^{24}$ Jangka waktu al-hijr yang dilakukan oleh informan pada masa konflik cukup beragama, hal ini bergantung pada kompleksitas masalah yang dihadapi. Adapun data yang ditemukan sebagai berikut:

\footnotetext{
${ }^{23}$ Moh. Nazir, Metodologi Penelitian ( Jakarta, Ghalia Indonesia, 1988), h.234.

${ }^{24}$ Direktorat Jenderal Badan Peradilan Agama, Data Faktor Penyebab Perceraian Nasional Tahun 2015 (online) (dapat diakses di http://infoperkara.badilag. net, tanggal 21 Maret 2015)
}

\begin{tabular}{lll}
\hline No. & Lama Pisah Ranjang & Jumlah \\
\hline 1. & 0 s.d 4 bulan & 3 pasangan \\
\hline 2. & 4 bulan s.d 1 tahun & 3 pasangan \\
\hline 3. & 1 tahun s.d 4 tahun & 4 pasangan \\
\hline
\end{tabular}

Data di atas menunjukkan bahwa hanya ada tiga pasangan yang melaksanakan praktik alhijr yang tidak melebihi batas maksimal yaitu kurang dari 4 bulan. Sementara itu, sebanyak 7 pasangan melakukan al-hijr di atas empat bulan, melebihi batas waktu maksimal yang ditetapkan ulama. Kondisi ini menunjukkan bahwa tidak banyak pasangan yang melaksanakan al-hijr sesuai dengan ajaran Islam. Selain lemahnya internalisasi ajaran Islam dalam kehidupan sehari-hari, praktik al-hijr yang melebihi batas maksimal disebabkan buruknya manajemen konflik dalam keluarga. Konflik yang terjadi dalam keluarga terus menerus terjadi tanpa ada proses jalan keluar yang cepat dan terbaik.

\section{Intensitas Komunikasi dalam Masa al-Hijr}

Salah satu tujuan praktik al-hijr yaitu meredam ego dan emosi masing-masing pihak dalam rangka menyelesaikan permasalahan yang ada. Berdasarkan hal ini, intensitas komunikasi menjadi elemen yang penting. Namun, hasil penelitian terhadap para pihak yang berperkara di Pengadilan Agama Kabupaten Malang menunjukkan bahwa intensitas komunikasi para pihak pada masa konsflik sangat rendah sebagaimana ditunjukkan tabel berikut:

\begin{tabular}{lll} 
No & Intensitas Komunikasi & Jumlah Pasangan \\
\hline 1. & Tidak komunikasi & 9 Pasangan \\
\hline 2. & Masih berkomunikasi & 1 pasangan \\
\hline
\end{tabular}

Para ulama telah memberikan panduan pelaksanaan al-hijr yaitu tidak melakukan komunikasi dan tidak melakukan hubungan seksual. Meskipun demikian, dua aktivitas tersebut harus diperhitungkan efektifitas dan tujuannya oleh para pihak yang berkonflik. Namun, data penelitian menunjukkan bahwa mayoritas pasangan yang melakukan al-hijr memutus komunikasi secara total. Menurut mereka sudah tidak ada gunanya lagi melakukan komunikasi karena dianggap akan memperparah percekcokan antara mereka. Para pihak yang berkonflik hanya bertemu di sidang Pengadilan 
Agama untuk mengurus perceraian. Buruknya kualitas komunikasi pasangan yang berperkara akan berpengaruh terhadap anak-anak. Pola interaksi dan cara komunikasi orang tua akan diikuti oleh putra-putri mereka secara langsung. Tidak jarang anak-anak yang orang tuanya bercerai akan melakukan perceraian juga ketika mereka sudah menikah. Karena mereka tidak mendapat pelajaran cara interaksi dan komunikasi yang baik pada saat terjadi konflik rumah tangga dari orang tua mereka.

Pada dasarnya, Islam tidak mengajarkan pola pisah ranjang dengan cara memutus komunikasi secara total. Akan tetapi memberikan jeda komunikasi agar satu sama lain melakukan introspeksi dan perbaikan. Secara psikologi, jeda komunikasi yang terprogram ini membantu pasangan dalam memecahkan problematika rumah tangga. Dinamika yang terjadi pada masa pisah ranjang dengan memutus komunikasi, sesungguhnya merupakan salah satu bentuk dari keinginan untuk setlle down dari para pasangan untuk menunda konflik dan konfrontasi serta menenangkan diri masing-masing. ${ }^{25}$ Namun apabila dilakukan dalam jangka waktu lama, maka akan memicu permasalahan yang baru seperti bibit perselingkuhan dengan rekan kerja ataupun mantan kekasih. Kenyamanan psikologis pada saat tidak berkomunikasi dengan pasangannya pada waktu yang lama, dapat menjadi pemicu terjadinya perceraian.

Masa al-hijr juga merupakan sarana untuk melakukan perenungan dan introspeksi terhadap kesalahan ataupun kekurangan masing-masing. Namun, data penelitian menunjukkan bahwa sebagian besar pasangan yang menjadi informan tidak memanfaatkan masa al-hijr sebagaimana tabel di bawah ini:

\begin{tabular}{lll}
\hline No. & $\begin{array}{l}\text { Pelaksanaan } \\
\text { Intropeksi }\end{array}$ & Jumlah Pasangan \\
\hline 1. & $\begin{array}{l}\text { Tidak melakukan } \\
\text { introspeksi }\end{array}$ & 7 pasangan \\
\hline 2. & Melakukan introspeksi & 3 pasangam \\
\hline
\end{tabular}

${ }^{25}$ Sadarjoen, Konflik Marital, Pemahaman Konseptual, Actual dan Alternative Solusinya (Bandung: Refika Aditama, 2005), h.8
Dari sepuluh pasangan yang diteliti, hanya ada tiga pasang saja yang melakukan introspeksi diri itupun dilakukan oleh salah satu pihak bukan kedua belah pihak. Sedangkan tujuh pasangan mengaku tidak melakukan kesalahan dan kekurangan yang berarti dalam masa perkawinan. Artinya mereka merasa sudah melakukan hak dan kewajiban sebagai suami ataupun istri dengan baik dan maksimal. Dalam proses al-hijr seharusnya seorang suami memberitahukan dan mendiskusikan perkara yang dianggap sebagai bentuk pembangkangan oleh istri. Sebelum proses tersebut dilakukan oleh suami, maka praktik al-hijr terlebih pemukulan merupakan sesuatu yang diharamkan dalam Islam. $^{26}$

Proses komunikasi yang kurang baik menjadikan konflik yang terjadi menjadi terus berkepanjangan di mana ego masing-masing suami istri belum melebur menjadi dalam satu ikatan yang kuat (mistâqan ghalîdzan). Setiap kesalahan dan kekurangan dalam diri suami istri seharusnya menjadi bahan untuk saling memaafkan dan memahami kekurangan satu sama lain. Kesalahan maupun kekurangan suami istri seharusnya tidak menjadikan mereka menjadi musuh yang berkepanjangan apabila masing-masing mau memaafkan, berlapang dada (tidak memarahi) dan mengampuni satu sama lain.

\section{Etika Pelaksanaan al-Hijr dalam Hukum Islam}

Beberapa aspek yang harus diperhatikan oleh para pasangan yang melakukan praktik al-hijr antara lain: a) Melokalisir konflik dalam wilayah domestik saja. Dalam arti tidak melibatkan banyak pihak dalam proses penyelesaian konflik untuk menghindari para pihak yang tidak memiliki kepentingan. Keterlibatan orang lain yang tidak berkepentingan dapat menimbulkan ekses negatif, misalnya fitnah atau perselingkuhan. Etika pelaksanaan al-hijr telah diajarkan oleh Rasulullah Saw., beliau bersabda:

${ }^{26} \mathrm{Al}-S y a f i ' i$, al-Umm, Juz V (Beirut: Dâr al-Ma'rifah, 1990), h.208 


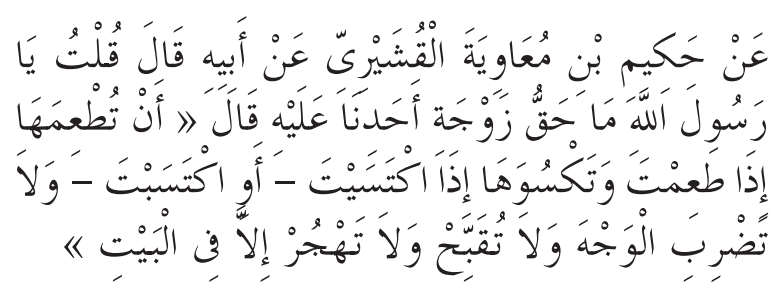

Artinya: dari Hakim ibn Mu'awiyyah al-Qusyairi dan Bapaknya, berkata: Aku bertanya wahai Rasulullah saw apa hak istri yang harus dipenuhi oleh kami. Rasulullah saw menjawab: kamu harus memberinya makan sebagaimana yang kamu makan, kamu harus memberinya pakaian sebagaimana yang kamu pakai atau yang sesuai dengan pekerjaanmu, jangan kamu pukul wajahnya dan jangan kamu menjelek-jelekannya dan jangan melakukan al-hijr (acuh) kepadanya kecuali di dalam rumah. ${ }^{27}$

Pelaksanaan al-hijr pada dasarnya dilakukan dengan melakukan pisah ranjang, dan terjadi hanya di dalam rumah. Pasangan yang berkonflik tidak diperbolehkan melakukan pisah ranjang di luar rumah. Selain itu, pasangan yang berkonflik tidak diperbolehkan untuk menampakkan rasa acuh para pihak di hadapan putra-putri mereka, tetap memenuhi kebutuhan atau memberikan nafkah kepada istri dan anak-anak. Karena pelaksanaan alhijr dimaksudkan untuk memberi pelajaran yang baik dan mencari jalan keluar bukan melakukan kekerasan secara fisik, ekonomi, seksual, maupun psikologis kepada istri. ${ }^{28}$

\section{Metode Pelaksanaan al-Hijr di Masyarakat}

Pelaksanaan al-hijr dalam khazanah figh dapat dilakukan dengan dua cara yaitu tidak melakukan komunikasi dan tidak melakukan hubungan seksual dengan istri. Namun, masyarakat lebih memahami al-hijr dengan pisah ranjang atau meninggalkan kediaman bersama. Praktik pisah ranjang yang dilakukan beberapa pasangan yang berperkara di Pengadilan Agama Kabupaten Malang ditemui data sebagai berikut:

\begin{tabular}{lll}
\hline No. & $\begin{array}{l}\text { Cara Pelaksanaan } \\
\text { Pisah Ranjang }\end{array}$ & Jumlah Pasangan \\
\hline
\end{tabular}

27

${ }^{28}$ Mahmûd al-Mishry Abu 'Imâr, al-Zawâj al-Islâmy al-Sa'îd (Kairo: Maktabah al-Shafa, 2006), h.773

\begin{tabular}{lll}
\hline 1. & $\begin{array}{l}\text { Suami meninggalkan } \\
\text { rumah }\end{array}$ & 8 Pasangan \\
\hline 2. & $\begin{array}{l}\text { Istri meninggalkan } \\
\text { rumah }\end{array}$ & 2 Pasangan \\
\hline
\end{tabular}

Data di atas menunjukkan bahwa proses pisah ranjang atau meninggalkan kediaman bersama tidak merepresentasikan konsep alhijr. Hal ini tidak terlepas dari kegagalan suami mewujudkan fungsi qawwam dalam keluarga. Misalnya sebagian besar suami justru hidup dan dihidupi oleh istri ataupun keluarga istri. Adapun latar belakang pasangan suami-istri ini melakukan pisah ranjang atau meninggalkan kediaman bersama sebagaimana berikut:

\begin{tabular}{lll}
\hline No. & $\begin{array}{l}\text { Latar Belakang } \\
\text { meninggalkan rumah }\end{array}$ & Jumlah Pasangan \\
\hline 1. & Cekcok & 3 pasangan \\
\hline 2. & Diusir suami & 2 pasangan \\
\hline 3. & Diusir istri/keluarga istri & 5 Pasangan \\
\hline \multicolumn{3}{c}{.Ada dua sebab utama suami meninggalkan }
\end{tabular}
kediaman bersama. Pertama, suami tidak tahan terus menerus bertengkar dengan istri ataupun keluarga istri. Suami lebih memilih menghindar untuk menyelesaikan masalahnya. Kedua, suami diusir oleh istri ataupun pihak keluarga istri karena lemahnya kedudukan suami dalam rumah tangga. Dua hal ini terjadi akibat lemahnya pemenuhan fungsi qawwam dalam keluarga.

\section{Pemberian Nafkah Lahir dalam Masa $A l$ - Hijr}

Pemberian nafkah merupakan kewajiban yang melekat dalam diri suami terhadap istri dan anak-anaknya. Sebagaimana tercantum dalam Q.S. al-Baqarah [2]: 233. Kewajiban ini masih melekat selama keduanya masih terikat dalam akad yang sah. Meskipun demikian, ada beberapa syarat seorang istri mendapatkan nafkah seperti: a) Suami istri berada pada akad yang sah; b) Istri menyerahkan diri sepenuhnya kepada suami; c) Istri merupakan wanita yang sudah layak dicumbu; d) Istri tidak menolak pindah ke tempat suami; e) Keduanya sudah mampu berhubungan suami istri. ${ }^{29}$ Pemberian nafkah ini tetap berlangsung

\footnotetext{
${ }^{29}$ Sayyid Sâbiq, Fiqh al-Sunnah (Beirut: Dar al-Kutub
} 
pada masa al-hijr.

Namun, hasil penelitian menunjukkan bahwa pelaksanaan pemberian nafkah lahir oleh suami yang berperkara di Pengadilan Agama pada masa al-hijr sebagaimana berikut:

\begin{tabular}{lll}
\hline No. & Pemberian Nafkah & Jumlah Pasangan \\
\hline 1. & Masih Memberi & 1 pasangan \\
\hline 2. & Tidak memberi & 9 pasangan \\
\hline
\end{tabular}

Data di atas menunjukkan bahwa sebagian besar suami setelah meninggalkan kediaman bersama dalam masa pisah ranjang, tidak pernah memberikan dan memperhatikan nafkah bagi istri dan anak-anak. Pemberian nafkah kepada istri yang melakukan nusyûz pada masa al-hijr para ulama berbeda pendapat. Sebagian ulama berpandangan bahwa hak nafkah istri menjadi hilang karena pembangkangan yang ia lakukan kepada suami. Meskipun demikian, Ibn Hazm tetap mewajibkan suami untuk memberikan nafkah selama suami istri berada pada akad pernikahan yang sah tanpa melihat istri melakukan nusyûz ataupun tidak. ${ }^{30}$ Menurut Ibn Hazm, Allah SWT dalam al-Nisa [4]: 34 hanya memberikan petunjuk bahwa tata cara menganggulangi nusyûz-nya istri adalah dengan tiga hal yaitu memberikan mauidzhah, al-hijr dan pemukulan tidak lebih dari itu. Apabila ada yang mengatakan bahwa itu merupakan hukuman bagi istri yang membangkang, maka Ibn Hazm berpendapat setiap kedzaliman tidak berarti menghilangkan hak yang bersifat materi bagi pelakunya kecuali ada nash alQur'an yang menetapkannya. Karena setiap kedzaliman tidak harus dibalas dengan kedzaliman pula. ${ }^{31}$ Pandangan Ibn Hazm di atas menarik untuk dicermati, karena boleh jadi sebab istri melakukan pembangkangan adalah karena tidak mampunya suami memberikan nafkah yang layak dan bertanggung jawab secara ekonomi.

Apabila dalam masa pisah ranjang ini suami justru enggan memberi nafkah kepada istri

al-'Araby, 1977), h.171

${ }^{30}$ Sayyid Sabiq, Fiqh Sunnah, Juz II (Beirut: Dâr alFikr, 1983), h.147

${ }^{31} \mathrm{Ibn}$ Hazm al-Andalusy, al-Muhalla bi al-Âtsâr, Juz IX (Beirut: Dâr al-Fikr, tt.), h.114 sebagaimana masa sebelumnya, maka kondisi ini akan menjadikan tekad istri untuk berpisah menjadi lebih besar. Dari para pihak yang berperkara yang menjadi informan penelitian, diketahui bahwa mayoritas diinisiasi oleh pihak istri, sebagaimana tabel berikut ini:

\begin{tabular}{lll}
\hline No. & Inisiator Cerai & Jumlah Pasangan \\
\hline 1. & Suami & 4 pasangan \\
\hline 2. & Istri & 6 pasangan \\
\hline
\end{tabular}

Selain itu, pemutusan nafkah seharusnya hanya dilakukan suami atas istrinya bukan kepada anaknya juga. Hal ini menunjukkan minimnya pemahaman dan kepatuhan serta tanggung jawab suami terhadap nafkah keluarga. Untuk itu, perlu ada proses edukasi dari para stakeholder misalnya pendidikan dan pemahaman kepada para calon pengantin agar masing-masing mengerti hak dan kewajibannya. Pasangan suami istri yang memiliki pengetahuan rumah tangga yang baik berdasarkan hukum Islam diharapkan dapat mewujudkan perkawinan yang sakinah, mawaddah dan rahmah.

\section{Pemberian Nafkah Batin dalam Masa al- Hijr}

Di samping nafkah lahir, nafkah batin merupakan kewajiban yang harus ditunaikan seorang suami atas istrinya. Allah SWT berfirman dalam Q.S. al-Nisa [4]: 19. Kewajiban pemberian nafkah batin tersebut oleh jumhur ulama selain Imam Syafi'i merupakan hal yang dapat dilakukan sesuai dengan kebutuhan suami-istri. Relasi dan keharmonisan dalam hubungan seksual merupakan salah satu cara agar rumah tangga berjalan dengan baik. Hubungan suami istri sesungguhnya dapat menjadi sarana alat rekreatif bagi suami istri yang mengalami masalah rumah tangga. Data penelitian ini menunjukkan bahwa pasangan yang berkonflik di pengadilan tidak ada yang pernah memberikan atau menerima nafkah batin sebagaimana tabel berikut: 


\begin{tabular}{lll}
\hline No. & Pelaksanaan Nafkah Batin & Jumlah Pasangan \\
\hline 1. & Tidak memberi nafkah batin & 10 pasangan \\
\hline 2. & Memberi nafkah batin & 0 pasangan \\
\hline
\end{tabular}

Dalam konteks al-hijr, tidak memberikan nafkah batin kepada istri merupakan salah satu cara memberi pelajaran kepada istri agar kembali taat dan patuh kepada suami. Akan tetapi, cara ini tidak mutlak harus dilakukan. Sebagian fuqaha berpendapat bahwa al-hijr tidaklah bermakna meninggalkan hubungan seksual dengan istri agar ia kembali kepada suami, akan tetapi al-hijr mengandung makna tidak mengajaknya berkomunikasi ketika tidur seranjang meskipun bisa jadi tetap melakukan hubungan seksual dengannya. Karena hubungan seksual adalah hak bersama sehingga tidak melakukan hubungan seksual dapat memberikan dampak kemadharatan bagi semua dan tidak memberi dampak edukatif bagi pasangan. ${ }^{32}$ Dengan lamanya tidak terjadi hubungan suami istri, terlebih apabila melebihi masa empat bulan semakin memberi dorongan dalam pengambilan keputusan untuk berpisah.

\section{Proses Perdamaian dalam Masa al-Hijr}

Dari hasil penelitian dapat diketahui bahwa proses perdamaian dalam masa al-hijr tidak dapat dilakukan secara optimal, baik oleh para pihak maupun atas bantuan pihak ketiga sebagaimana tabel berikut:

\begin{tabular}{lll}
\hline No. & Pelaksanaan Mediasi & Jumlah Pasangan \\
\hline 1. & Pernah dimediasi & 2 pasangan \\
\hline 2. & Tidak pernah dimediasi & 8 pasangan \\
\hline
\end{tabular}

Masa pisah ranjang seharusnya menjadi sarana mendamaikan suami istri yang sedang berkonflik. Upaya tersebut dapat dilakukan oleh pihak keluarga ataupun masyarakat melalui tokoh-tokoh yang disegani seperti kyai, ustad, sesepuh/ketua adat, ketua RT, ketua RW ataupun kepala desa. Kehadiran pihak ketiga dalam menyelesaikan problem rumah tangga akibat nusyûz hingga menyebabkan syiqaq diafirmasi dengan perintah Allah SWT dalam

\footnotetext{
${ }^{32}$ Kementerian Wakaf dan Urusan Agama Kuwait, Mausû'ah al-Fighiyyah (Kuwait:Dâr al-Salâsil, 1427 H), h.297
}

Q.S. al-Nisa [4]: 35 yang berbunyi:

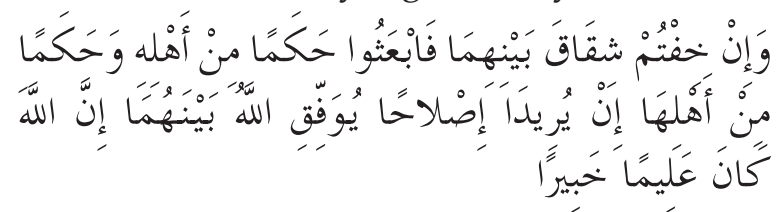

Artinya: Dan jika kamu khawatirkan adápersengketaan antara keduanya, maka kirimlah seorang hakam dari keluarga laki-laki dan seorang hakam dari keluarga perempuan. Jika kedua orang hakam itu bermaksud mengadakan perbaikan, niscaya Allah memberi taufik kepada suami-istri itu. Sesungguhnya Allah Maha Mengetahui lagi Maha Mengenal.

Keluarga merupakan struktur terkecil dan memegang peranan sentral dalam masyarakat. Sehingga terwujudnya keharmoninas rumah tangga merupakan tanggungjawab bersama, tidak hanya suami-istri saja. Untuk itu perlu dibuat lembaga-lembaga penasehat perkawinan yang profesional dan kompeten dalam menangani perselisihan rumah tangga secara intensif. Secara intensif bermakna proses perdamaian tersebut tidak hanya dilakukan satu kali saja untuk menggugurkan kewajiban. Akan tetapi proses perdamaian dilakukan secara berkala dan terus menerus dan termonitoring dengan baik agar tidak menambah efek negatif kepada keluarga dan masyarakat. Selain itu, aktivitas ini harus dilakukan secara cepat dan tepat tanpa menunggu konflik terjadi secara lebih keras dan meluas. Kegagalan dalam proses mediasi tersebut biasanya karena konflik sudah terlanjur meluas dan parah. Dari pasangan suami-istri yang menjadi informan penelitian, hanya dua pasangan yang pernah melakukan mediasi, sedangkan pasangan yang lain tidak pernah dimediasi. Akibatnya, pasca perceraian dimungkinkan masih terjadi perselisihan mengenai banyak hal seperti nafkah, harta gono gini dan hak hadhanah. Perceraian yang seharusnya menjadi pemutus konflik malah menjadi awal dari konflik yang baru. Padahal proses perkawinan ataupun perceraian hanya berdasarkan kepada dua hal sebagaimana dalam Q.S. al-Baqarah [2]: 229 yaitu tetap menikah dengan cara yang ma'ruf ataupun berpisah dengan cara yang baik. 


\section{Kesimpulan}

Berdasarkan data dan pembahasan di atas dapat disimpulkan beberapa hal sebagai berikut: Pertama, praktik al-hijr yang dilakukan oleh pasangan yang bercerai di Pengadilan Agama Kabupaten Malang disebabkan beberapa hal seperti perselingkuhan, pertengkaran dan perselisihan yang berkepanjangan, pengusiran oleh satu pihak yang sebagaian besar dilakukan istri atau keluarganya kepada suami. Kedua, pelaksanaan al-hijr yang dilakukan oleh pasangan suami istri yang berperkara di Pengadilan Agama Kabupaten Malang belum sesuai dengan hukum Islam. hal ini sebabakan adanya masa yang melebihi batas maksimal yaitu empat bulan. Selain itu, sebagian besar pasangan

\section{DAFTAR PUSTAKA}

'Amâr, Mahmûd al-Mishry Abu . al-Zawâj al-Islâmy al-Sa'îd. Kairo: Dar al-Shafa. 2006

‘Imâr, Mahmûd al-Mishry Abu. al-Zawâj al-Islâmy al-Sa'îd. Kairo: Maktabah alShafa. 2006

al-Andalusy, Ibn Hazm. al-Muhalla bi al-Âtsâr, Juz IX. Beirut: Dâr al-Fikr, tt

al-Marâghi, Ahmad Musthofa. Tafsîr al-Marâghi, Juz V. Mesir: Maktabah Musthofa al-Baby al-Halaby.1986

Al-Marâghi, Tafsîr al-Marâghy, Jilid V. Kairo: Musthafa al-Bâby al-Halaby. 2005

al-Râzy, Fakr al-Dîn. Mafâtîh al-Ghaib, Juz X. Beirut: Dâr Ikhyâ al-Turâts. $1420 \mathrm{H}$

al-Shâbûny, Muhammad 'Ali. Mukhtashar Ibn Katsîr, Juz I. Beirut: Dâr al-Qur'an al-Karîm. 1981.

Al-Syafi'i, al-Umm, Juz V. Beirut: Dâr alMa'rifah. 1990

al-Zuhaily, Wahbah al-Fiqh al-Islâmy wa Adillatuh,Juz IX. Damaskus: Dâr alFikr. 2006

al-Zujâj, Abu Ishâq. Ma'ani al-Qur'an wa I'râbuh, Juz II. Beirut: 'Âlam al-Kutub. 1988

Amiruddin dan Zainal Asikin, Pengantar Metode Penelitian Hukum. Jakarta: PT Grafindo Persada. 2004 melakukan al-hijr dengan cara meninggalkan rumah, memutus komunikasi, dan nafkah lahir batin yang kebanyakan dilakukan oleh suami. Padahal dalam konsep al-hijr suami seharusnya sebagai pihak yang memegang peranan qawwâmah (pengayom) bagi istri bukan sebaliknya. Ketiga, para pasangan yang berkonflik tidak melakukan introspeksi dan negosiasi dalam rangka memecahkan masalah bersama. Hal ini diperburuk dengan kendala komunikatif sehingga upaya memperbaiki hubungan rumah tangga tidak berjalan secara maksimal.

Daud, Abu. Sunan Abi Daud, Juz II. Beirut: Maktabah al-'Ashriyyah. tt

Direktorat Jenderal Badan Peradilan Agama, Data Faktor Penyebab Perceraian Nasional Tahun 2015 (online) (dapat diakses di http://infoperkara.badilag.net, tanggal 21 Maret 2015)

Direktorat Jenderal Badan Peradilan Agama, Data Jenis Perkara Nasional Tahun 2015 (online) (dapat diakses di http:// infoperkara.badilag.net, tanggal 21 Maret 2015)

http://www.vemale.com/relationship/intim/16399pisah-ranjang-memperkuat-ikatansuami-istri.html

Kementerian Wakaf dan Urusan Agama Kuwait, Mausû'ah al-Fiqhiyyah. Kuwait:Dâr alSalâsil. $1427 \mathrm{H}$

Moelong, Lexy J. Metodologi Penelitian Kuantitatif. Bandung: PT Rosda karya. 2002

Muslim, Shahîh Muslim, juz IV (Beirut: Dâr Ikhyâ al-Turâts al-'Araby, tt), 1984

Nawawi. Minhâj al-Thâlibîn wa 'Umdat alMuftîn fi al-Fiqh. Beirut: Dâr al-Fikr. 2005

Nawawi. Raudhat al-Thâlibîn wa 'Umdat al-Muftîn, Juz VII. Beirut: al-Maktab al-Islâmy. 1991 
Nazir, Moh. Metodologi Penelitian. Jakarta, Ghalia Indonesia. 1988

Sabiq, Sayyid. Fiqh Sunnah, Juz II. Beirut: Dâr al-Fikr, 1983

Sabiq, Sayyid. Fiqh al-Sunnah. Beirut: Dar al-Kutub al-'Araby. 1977
Sadarjoen. Konflik Marital, Pemahaman Konseptual, actual dan Alternative Solusinya. Bandung: Refika Aditama. 2005

Sugiyono. Metode Penelitian Pendekatan Kuantitatif, Kualitatif dan R\&D. Bandung: Alfabeta, 2007

Syarbîny, Mughni al-Muhtâj, Juz IV. Beirut: Dâr al-Kutub al-'Ilmiyyah. 1994 